\title{
Scanning Electron Microscopy Studies and In Vitro Regeneration of Passiflora edulis Sims var. edulis for Conservation
}

\author{
Rubashiny Veeramohan, Noorma Wati Haron, and Rosna Mat Taha
}

\begin{abstract}
In this study, different combinations of benzylaminopurine (BAP) and naphthalene acetic acid (NAA) were used to establish an efficient in vitro regeneration in two different types of explants: stem and shoot tip of seedlings obtained from in vitro seed germination of Passiflora edulis Sims var. edulis. The results obtained showed that BAP induced shoots while NAA induced roots. Scanning Electron Microscopy (SEM) studies were carried out to observe and differentiate the morphology of in vitro and in vivo grown Passiflora edulis Sims var. edulis. SEM techniques were done to observe the stomata and microcharacters of both the abaxial and adaxial surfaces of in vitro and in vivo leaves of Passiflora edulis Sims var. edulis.
\end{abstract}

Index Terms-In vitro, in vivo, Passiflora edulis Sims var. edulis, regeneration, Scanning Electron Microscopy (SEM).

\section{INTRODUCTION}

The family Passifloraceae consists of 18 genera and about 630 species, most of which are tendril climbing vines native to warm regions of the world [1]. In America, the family is represented by four genera (Ancistrothyrsus, Dilkea, Mitostemma and Passiflora), of which Passiflora is numerically and economically the most important genus of the family. There are about 500 species of Passiflora worldwide, but only less than 10 species could be found in Malaysia. Passiflora edulis Sims is considered as the most important species of the genus Passiflora, mainly because of its botanical and commercial value, as well as for crop breeding and genomic programs.

Passiflora edulis Sims var. edulis is also known as purple passion fruit and is a vigorous perennial woody climber. It is originated in the Amazon region of Brazil, but has been commercially cultivated in Hawaii, Australia, New Zealand, Fiji, South Africa and Kenya [2]-[4]. In Malaysia, it is widely distributed in the northern, east coast, and central regions. The leaves are green and alternate, turning into 3 lobed leaves when they mature. The bisexual solitary flower is borne at leaf base of new growth. It is about 4 to $5 \mathrm{~cm}$ in diameter and very conspicuous, colourful and fragrant. It has five whitish petals and two purplish rows of thread like rays called corona The pistil consists of an ovary tripartite style, each branch terminating in a sticky stigma. The fruit is round or oval, about 4 to $5 \mathrm{~cm}$ long and greenish yellow or purple when ripe

Manuscript received March 4, 2013; revised May 3, 2013. This work was supported in part by the University of Malaya under Grants of PPP PS299/2010B and UMRG RG037/09SUS.

All the authors are with the Institute of Biological Sciences, Faculty of Science, University of Malaya, 50603 Kuala Lumpur, Malaysia (e-mail: ruvee19@gmail.com,noorma@um.edu.my,rosna@um.edu.my). and smooth [2]. They grow swiftly about 15 to 20 feet per year [4].

Passiflora edulis Sims var. edulis is widely grown in the tropics for its edible fruits as they are good sources of Vitamins A and C. The fruit has anticarcinogenic effects and the pulp acts as a stimulant and tonic. The flower extract of Passiflora edulis has sedative and hypnotic effects. Glycosides, phenols and alkaloids are the major constituents in Passiflora edulis [3], [4]. The identified constituents in Passiflora edulis includes anthocyanins, carotenoids, $\gamma$-lactones, 1-ascorbic acid, flavour components, volatile oil constituents, minerals, amino acids, carbohydrates, the cytoplasmic enzyme pyruvate kinase, cycloartane triterpenes, cyclo passiloic acids A-D, and their saponins, cyclopassi-flosides I-VI [4], [5].

Tissue culture studies of Passiflora started as early as 1966 and since then many reports on tissue culture based methods applied to the genus have been published [6]. Most of the in vitro culture techniques for Passiflora were developed using Passiflora edulis Sims f. flavicarpa Deg. explants and have been used for micropropagation [7], [8], organogenesis [9], somatic hybridization [10], [11], and genetic transformation [9] of the species. Organogenesis-based plant regeneration system is currently being established in passion fruit [6], [11]. However, reports on in vitro plant regeneration and taxonomic studies of Passiflora edulis Sims var. edulis are scanty especially on the micromorphological aspects. Therefore, the objectives of this study were to study the influence of different combinations of BAP and NAA hormones on in vitro regeneration, to observe and differentiate the characteristics of Passiflora edulis Sims var. edulis grown in vivo and in vitro via Scanning Electron Microscopy (SEM), and to increase micromorphological taxonomic information of Passiflora edulis Sims var. edulis.

\section{MATERIALS AND METHODS}

\section{A. Seed Germination}

Seeds of Passiflora edulis Sims var. edulis were obtained from ripe fruits collected from the Institute of Biological Sciences garden in University of Malaya, Kuala Lumpur. Seeds were germinated via in vitro and in vivo techniques. The pulps were removed completely to be cultured in vitro and in vivo using aseptic techniques to obtain explants from seedlings. The seeds were then washed under running tap water for 30 minutes and treated with $70 \%, 50 \%$, and $20 \%$ $(\mathrm{v} / \mathrm{v})$ commercial bleach for 10 minutes at each concentration. Next, seeds were rinsed in distilled water for 2 minutes and 
transferred to the laminar flow chamber. Surface sterilization of seeds was done using $70 \%$ (v/v) of ethanol for 30 seconds, followed by three rinses in sterile distilled water and left to air-dry in the laminar flow chamber. Sterilized seeds were germinated in jam jars containing Murashige and Skoog (MS) salt and vitamins supplemented with $3 \%$ sucrose and $0.8 \%$ agar for in vitro germination. The $\mathrm{pH}$ of the media was adjusted to $5.8 \pm 0.1$ before autoclaving at $121^{\circ} \mathrm{C}$ for 20 minutes. Twenty replicates were used for each experiment and maintained at $25 \pm 2^{\circ} \mathrm{C}$ with 16 hours of light and 8 hours of dark. Whereas, for in vivo germination, seeds of Passiflora edulis Sims var. edulis were germinated on the soil in a small pot and watered daily. In vivo grown plants were then used for micromorphological comparison with in vitro plantlets.

\section{B. Scanning Electron Microscopy (SEM) Studies}

Passiflora edulis Sims var. edulis leaf specimens were collected from the Institute of Biological Sciences garden in University of Malaya, Kuala Lumpur. Leaves were cut in square shape with measurement of approximately $3 \mathrm{~mm} \times 3$ $\mathrm{mm}$ and soaked in a mixed solution of $8 \%$ Glutaraldehyde and Sorencen's Buffered Phosphate with a ratio of 1:1 for an hour. The leaf specimens were washed with Sorencen's Buffered Phosphate solution and distilled water with a ratio of $1: 1$ for 5 minutes. Specimens were then soaked in a mixed solution of $4 \%$ Osmium and distilled water with a ratio of $1: 1$. After about 14 hours at low temperature, the dehydration process was conducted in vessel fumes. The concentration of ethanol was increased for every 15 minutes, from $10 \%$ until it reaches $100 \%$. Specimens were soaked in mixture of $100 \%$ ethanol and $100 \%$ acetone with ratios of $3: 1,1: 1$, and $1: 3$ for 20 minutes respectively. Right after that, the leaf specimens were then soaked in $100 \%$ acetone solution for 20 minutes, repeating them for four times. Next, the method of Critical Point Drying (CPD) was conducted using Bal-Tec CPD 030 Critical Point Dryer. Specimens were mounted on aluminium with diameter of $12.5 \mathrm{~mm}$ using Conducting Carbon Cement (LEIT-C), kept in a drying jar, and coated with a thin layer of gold (40-60 nm) by using BIO-Rod SEM Coating System. Structures such as stomata and the abaxial and adaxial surfaces structure of the leaves were observed under the scanning electron microscope and recorded.

\section{In Vitro Regeneration}

After 60 days, stem $(1 \mathrm{~cm})$ and shoot tip $(1 \mathrm{~cm})$ explants were excised into specific measurements from seedlings to be inoculated in culture tubes containing MS medium [12] supplemented with agar and $0.5 \mathrm{mg} / \mathrm{L} \mathrm{BAP}+0.5-2.0 \mathrm{mg} / \mathrm{L}$ $\mathrm{NAA}$ and $0.5 \mathrm{mg} / \mathrm{L} \mathrm{NAA}+0.5-2.0 \mathrm{mg} / \mathrm{L} \mathrm{BAP}$. The $\mathrm{pH}$ of the medium was adjusted to $5.8 \pm 0.1$ prior to autoclaving (20 minutes at $120^{\circ} \mathrm{C}$ ). The cultures were then incubated in a culture room at $25 \pm 2^{\circ} \mathrm{C}$ under a regular cycle of 16 hours of light and 8 hours of dark. Observations were made and the data obtained was subjected to statistical analysis for computation of the standard error of the mean (SE). A completely randomized design with 20 replications for each explant was used. Observations of each explant were made after 45 days of culture. Data obtained were analyzed using Duncan's Multiple Range Test (DMRT). Mean with different letters in the same row differ significantly at $p=0.05$.

\section{RESULTS}

\section{A. Scanning Electron Microscopy (SEM) Analysis}

Figs. 1(a) \& 2(b) shows that Passiflora edulis Sims has papillose epidermal surface, with undulating anticlinal wall on the abaxial surface (Fig. 2(b)). Fig. 2(c) shows the absence of stomata and irregularly shaped polygonal epidermal on the adaxial surface. Epicuticular wax is sparsely distributed on the surface. Referring to Figs. 1(b) and 2(b), the paracytic stoma of an in vitro species has stomata measurement of 11.0 $\mu \mathrm{m}$ by length and $8.82 \mu \mathrm{m}$ by width, while the in vivo Passiflora edulis Sims leaf measures $13.4 \mu \mathrm{m}$ by length and $10.1 \mu \mathrm{m}$ by width. Stomata were absent on the adaxial surfaces of both in vitro and in vivo species (Figs. 1(c) \& 2(c)).

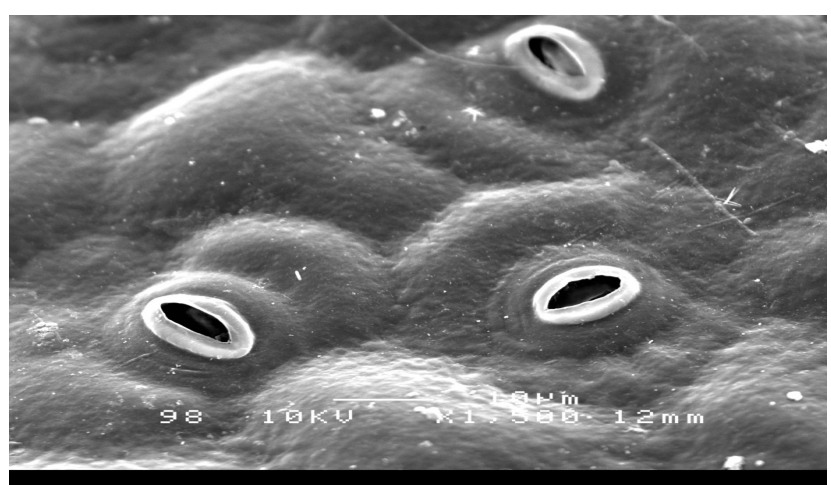

Fig. 1(a). Abaxial surface of an in vivo Passiflora edulis Sims leaf.

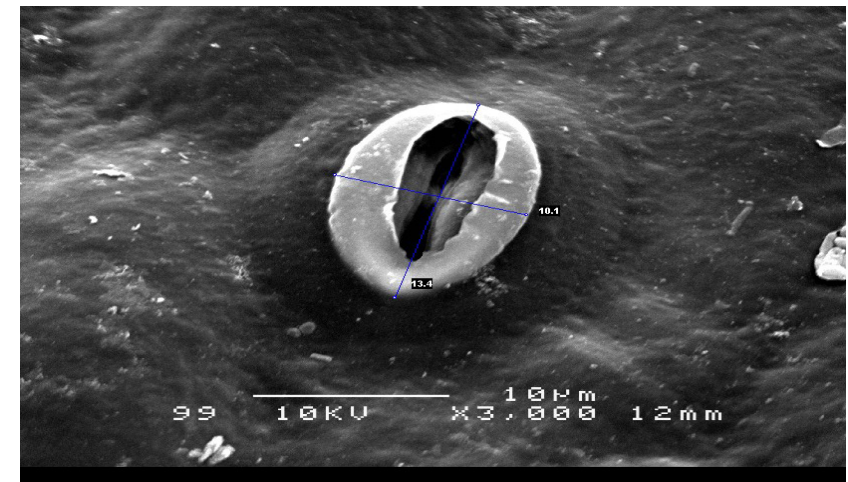

Fig. 1(b). Stoma on the abaxial surface of an in vivo Passiflora edulis Sims leaf.

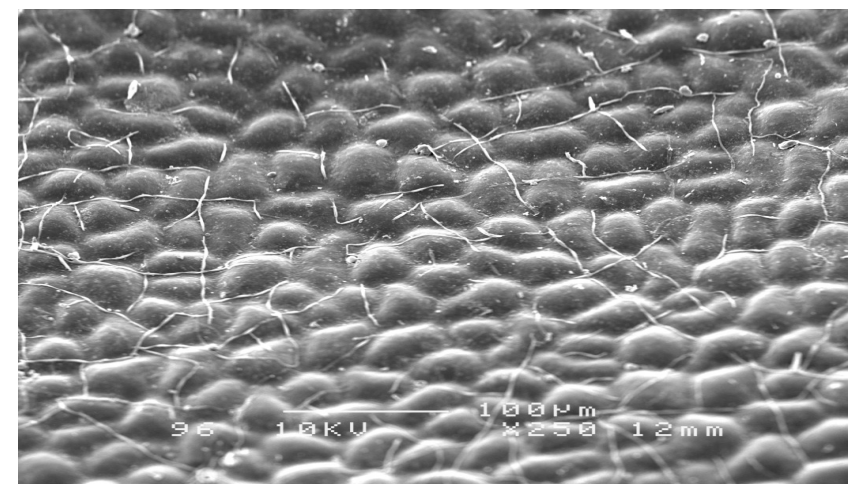

Fig. 1(c). Adaxial surface of an in vivo Passiflora edulis Sims leaf. 


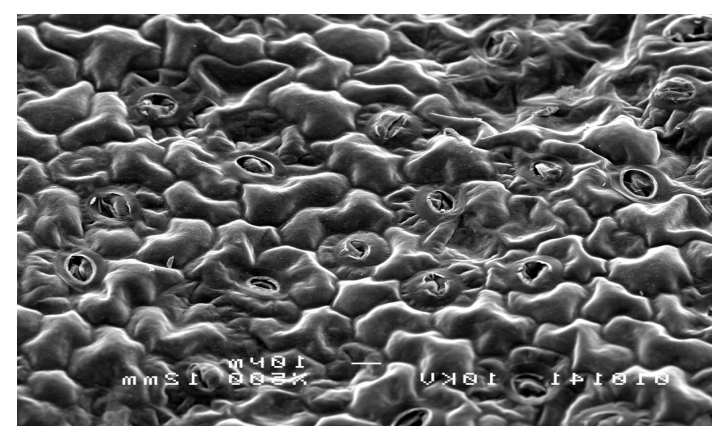

Fig. 2(a). Abaxial surface of an in vitro Passiflora edulis Sims leaf.

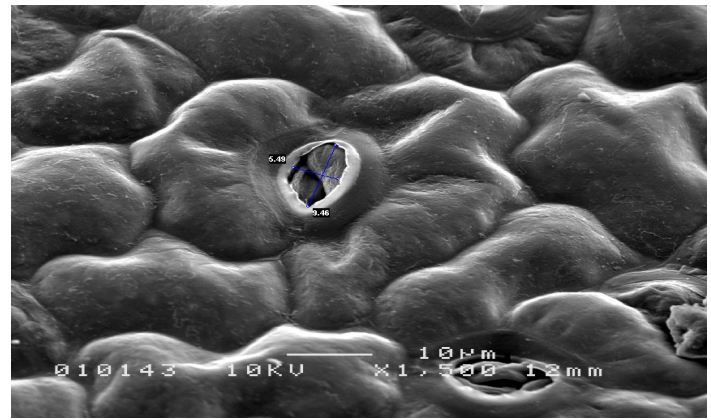

Fig. 2(b). Stomata on the abaxial surface of an in vitro Passiflora edulis Sims

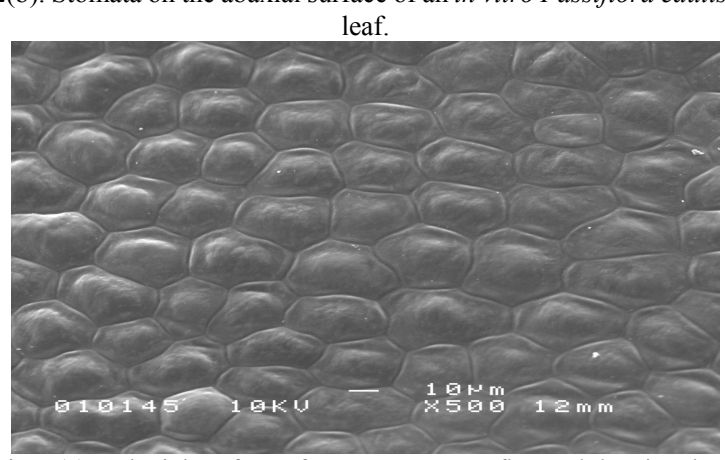

Fig. 2(c). Adaxial surface of an in vitro Passiflora edulis Sims leaf.

\section{B. In Vitro Regeneration}

Passiflora edulis Sims var. edulis seeds that were germinated in vitro in MS media without hormone supplement gave $90 \%$ response of healthy seedlings within 60 days. Table I shows that the highest average shoot number was exhibited by shoot tip explants cultured on MS media supplemented with $0.5 \mathrm{mg} / \mathrm{L} \mathrm{NAA}+2.0 \mathrm{mg} / \mathrm{L}$ BAP which produced $2.70 \pm 0.22$ average shoot (Fig. 3). The highest average shoot number produced was significantly different from all plant growth regulator combinations, except 0.5 $\mathrm{mg} / \mathrm{L}$ NAA $+1.0-1.5 \mathrm{mg} / \mathrm{L}$ BAP. Stem explants cultured on MS media fortified with $0.5 \mathrm{mg} / \mathrm{L} \mathrm{BAP}+0.5 \mathrm{mg} / \mathrm{L} \mathrm{NAA}$ and $0.5 \mathrm{mg} / \mathrm{L} \mathrm{NAA}+2.0 \mathrm{mg} / \mathrm{L} \mathrm{BAP}$ which showed the highest average shoot number of $1.25 \pm 0.29$ and $1.25 \pm 0.30$ respectively, were significantly different from all the other plant growth regulator combinations except for $0.5 \mathrm{mg} / \mathrm{L}$ $\mathrm{NAA}+1.0 \mathrm{mg} / \mathrm{L} \mathrm{BAP}$, which resulted in an average shoot number of $1.05 \pm 0.19$. Stem explants produced an average root number of $4.90 \pm 2.42$ and shoot explants produced an average root number of $5.10 \pm 2.28$ in MS media supplemented with $0.5 \mathrm{mg} / \mathrm{L}$ BAP $+1.5 \mathrm{mg} / \mathrm{L}$ NAA. Stem explants cultured on MS media supplemented with $0.5 \mathrm{mg} / \mathrm{L}$ $\mathrm{BAP}+1.5-2.0 \mathrm{mg} / \mathrm{L}$ NAA which produced an average root number of $4.90 \pm 2.42$ and $1.65 \pm 0.47$, respectively, were significantly different from responses exhibited by other plant growth regulator combinations. The average number of roots produced by shoot tip explants $(5.10 \pm 2.28)$ in $\mathrm{MS}$ media fortified with $0.5 \mathrm{mg} / \mathrm{L} \mathrm{BAP}+1.5 \mathrm{mg} / \mathrm{L}$ NAA was significantly different from responses showed by other plant growth regulator concentrations.

\section{Discussion}

Based on the SEM observation of Figs. 1(a) \& 2(b), the abaxial anticlinal wall of in vitro species appears to be more undulated compared to the in vivo species. The smaller size of an in vitro Passiflora edulis Sims var. edulis stomata compared to the in vivo species stomata may be due to the age differences between the in vivo and in vitro species. It is also observed that the stomata of in vitro species were sunken compared to the stomata of in vivo species. This may be due to the low relative humidity and high $\mathrm{CO}_{2}$ concentration in the culture vessel during the photoperiod [13].

In this work, shoot formation was observed in shoot tips explants for all treatments, including the control. On the other hand, stem explants formed shoots on all treatments, except for the control. Root formation was absent in stem explants cultured in MS media supplemented with $0.5 \mathrm{mg} / \mathrm{L} \mathrm{BAP} \mathrm{+}$ $0.5 \mathrm{mg} / \mathrm{L}$ NAA and the control treatment, whereas shoot tip explants showed root formation only on MS media supplemented with $0.5 \mathrm{mg} / \mathrm{L} \mathrm{BAP}+1.5 \mathrm{mg} / \mathrm{L}$ NAA (Table I).

TABLE I: THE INFLUENCES OF MS MEDIA SUPPLEMENTED WITH VARIOUS HORMONE COMBINATIONS OF BAP AND NAA ON SHOOT AND ROOT REGENERATION FROM STEM AND SHOOT TIP EXPLANTS OF PASSIFLORA EDULIS AFTER 45 DAYS IN CULTURE

\begin{tabular}{|c|c|c|c|c|c|}
\hline \multicolumn{2}{|c|}{$\begin{array}{c}\text { PGR } \\
\text { Concentrati } \\
\text { on }(\mathrm{mg} / \mathrm{L}) \\
\end{array}$} & \multicolumn{2}{|c|}{ Stem explants } & \multicolumn{2}{|c|}{ Shoot tip explants } \\
\hline $\begin{array}{c}\text { BA } \\
P\end{array}$ & NAA & $\begin{array}{l}\text { Average } \\
\text { shoot no. } \\
( \pm \mathrm{SE})\end{array}$ & $\begin{array}{l}\text { Average } \\
\text { root no. } \\
( \pm \mathrm{SE})\end{array}$ & $\begin{array}{c}\text { Average } \\
\text { shoot no. } \\
( \pm \mathrm{SE})\end{array}$ & $\begin{array}{l}\text { Average } \\
\text { root no. } \\
( \pm \mathrm{SE})\end{array}$ \\
\hline 0 & 0 & $0.05 \pm 0.05 \mathrm{~d}$ & $0.00 \pm 0.00 \mathrm{~b}$ & $0.00 \pm 0.00 \mathrm{~d}$ & $0.00 \pm 0.00 \mathrm{~b}$ \\
\hline 0.5 & 0.5 & $1.25 \pm 0.29 \mathrm{a}$ & $0.00 \pm 0.00 \mathrm{~b}$ & $1.35 \pm 0.22 b$ & $0.00 \pm 0.00 \mathrm{~b}$ \\
\hline 0.5 & 1 & $\begin{array}{c}0.70 \pm 0.16 b \\
\mathrm{c}\end{array}$ & $0.55 \pm 0.20 \mathrm{~b}$ & $0.20 \pm 0.09 \mathrm{~d}$ & $0.00 \pm 0.00 \mathrm{~b}$ \\
\hline 0.5 & 1.5 & $\begin{array}{c}0.40 \pm 0.11 \mathrm{c} \\
\mathrm{d}\end{array}$ & $4.90 \pm 2.42 \mathrm{a}$ & $\begin{array}{c}0.40 \pm 0.11 \mathrm{c} \\
\mathrm{d}\end{array}$ & $5.10 \pm 2.28 \mathrm{a}$ \\
\hline 0.5 & 2 & $\begin{array}{c}0.50 \pm 0.12 \mathrm{c} \\
\mathrm{d}\end{array}$ & $1.65 \pm 0.47 \mathrm{a}$ & $0.75 \pm 0.10 \mathrm{c}$ & $0.00 \pm 0.00 \mathrm{~b}$ \\
\hline 1 & 0.5 & $\begin{array}{c}1.05 \pm 0.19 \mathrm{a} \\
\mathrm{b}\end{array}$ & $0.00 \pm 0.00 \mathrm{~b}$ & $2.40 \pm 0.11 \mathrm{a}$ & $0.00 \pm 0.00 \mathrm{~b}$ \\
\hline 1.5 & 0.5 & $\begin{array}{c}0.75 \pm 0.23 b \\
\mathrm{c}\end{array}$ & $0.00 \pm 0.00 \mathrm{~b}$ & $2.60 \pm 0.21 \mathrm{a}$ & $0.00 \pm 0.00 \mathrm{~b}$ \\
\hline 2 & 0.5 & $1.25 \pm 0.30 \mathrm{a}$ & $0.00 \pm 0.00 \mathrm{~b}$ & $2.70 \pm 0.22 \mathrm{a}$ & $0.00 \pm 0.00 \mathrm{~b}$ \\
\hline
\end{tabular}

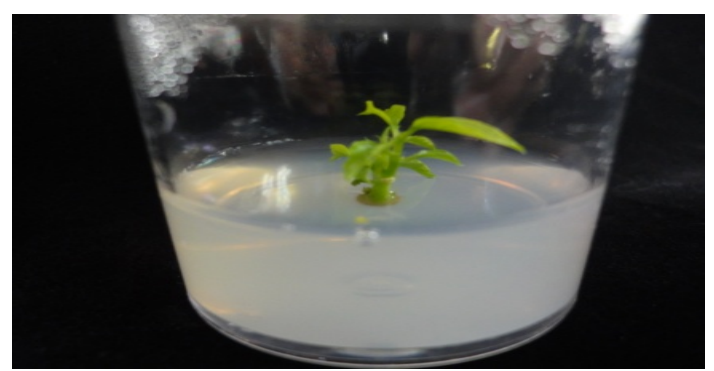

Fig. 3. Multiple shoots formation on MS Media $+0.5 \mathrm{mg} / \mathrm{L} \mathrm{NAA}+2.0 \mathrm{mg} / \mathrm{L}$ BAP 


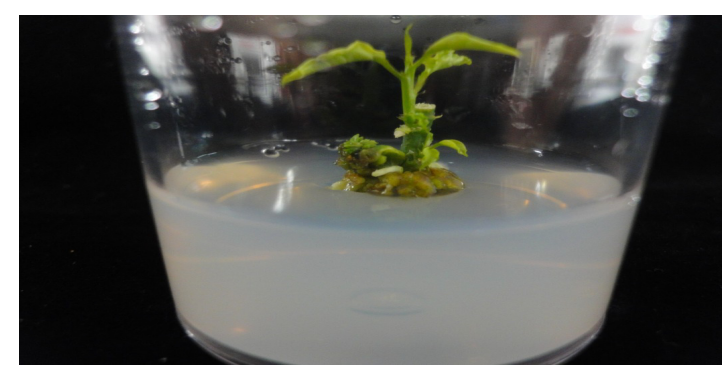

Fig. 4. Plantlet regeneration from stem explant cultured on MS media +0.5 $\mathrm{mg} / \mathrm{L} \mathrm{BAP}+1.5 \mathrm{mg} / \mathrm{L} \mathrm{NAA}$.

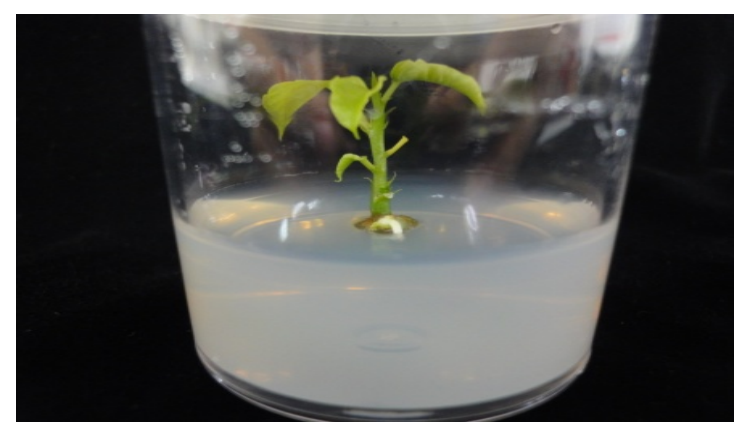

Fig. 5. Plantlet regeneration from shoot tip explant cultured on MS media + $0.5 \mathrm{mg} / \mathrm{L} \mathrm{BAP}+1.5 \mathrm{mg} / \mathrm{L} \mathrm{NAA}$.

There are a number of plant regeneration reports available on Passiflora using various explants and plant growth regulators combinations [14], [15]. Reference [16] reported plant regeneration through leaf discs of passion fruit using kinetin, BAP, and NAA. They also discussed that callus and roots could be induced in leaf discs of Passiflora edulis Sims f. flavicarpa Deg. by altering the concentration of cytokinin and auxin. Roots were obtained when NAA was used but no roots were obtained with the use of indoleacetic acid (IAA) or indolebutyric acid (IBA). Based on this work, roots were obtained from stem and shoot tip explants of Passiflora edulis Sim var. edulis in combinations of both BAP and NAA plant growth regulators. Reference [17] found that lower concentration of NAA induced lower root formation. Proportionally, higher concentration of NAA induced higher root formation in this research. Indirect plant regeneration was observed from stem and shoot tip explants cultured on $\mathrm{MS}+0.5 \mathrm{mg} / \mathrm{L} \mathrm{BAP}+1.5 \mathrm{mg} / \mathrm{L}$ NAA (Figs. 4 \& 5), which shows a great potential to carry out mass propagation of this plant. These in vitro grown complete plantlets could be transferred from the culture room to pots outside through a process of acclimatization.

\section{CONCLUSION}

From the present study, it was found that the abaxial anticlinal wall of in vitro Passiflora edulis Sims var. edulis leaf is more undulated compared to the in vivo species. The stomata of in vitro Passiflora edulis Sims var. edulis are smaller in size compared to the stomata size of in vivo grown plant which may be due to the age differences between the in vivo and in vitro grown plant. This study has also added new taxonomic information especially on the micromorphological aspects of the species.

Stem and shoot tip explants cultured on MS media supplemented with $0.5 \mathrm{mg} / \mathrm{L}$ BAP and $0.5-2.0 \mathrm{mg} / \mathrm{L}$ NAA and MS media fortified with $0.5 \mathrm{mg} / \mathrm{L}$ NAA and $0.5-2.0$ $\mathrm{mg} / \mathrm{L}$ BAP showed different responses of indirect organogenesis. Generally, MS media supplemented with 0.5 $\mathrm{mg} / \mathrm{L}$ BAP and $1.5 \mathrm{mg} / \mathrm{L}$ NAA was optimum for plant regeneration of Passiflora edulis Sims var. edulis. Further research should be conducted to study the possibilities of inducing mass micropropagation through in vitro regeneration of Passiflora edulis Sims var. edulis.

\section{ACKNOWLEDGMENT}

The authors would like to thank University of Malaya for the financial support (Grants: PPP PS299/2010B and UMRG RG037/09SUS) and the facilities provided by the B2.5 Tissue Culture Lab. Rubashiny Veeramohan would also like to thank the supervisors, Mr. Saiful, and lab members for all the unconditional help and support they provided to successfully carry out this research.

\section{REFERENCES}

[1] D. F. Waterhouse, Biological Control of Weeds: Southeast Asian Prospects, Monographs, Australian Centre for International Agricultural Research, pp. 184 - 207, 1994.

[2] M. B. Banu, M. Q. I. Matin, T. Hossain, and M. M. Hossain, "Flowering behaviour and flower morphology of passion fruit (Passiflora edulis Sims)," International Journal of Sustainable Crop Production, vol. 4, no. 4, pp. 5-7, August 2009.

[3] S. S. Patel, "Morphology and pharmacology of Passiflora edulis: A review," Journal of Herbal Medicine and Toxicology, vol. 3, no. 1, pp. $1-6,2009$.

[4] F. A. Ripa, M. Haque, L. Nahar, and M. M. Islam, "Antibacterial, cytotoxic and anti-oxidant activity of Passiflora edulis Sims," European Journal of Scientific Research, vol. 3, no. 4, pp. 592-598, 2009.

[5] K. Yoshikawa, S. Katsuta, J. Mizumori, and S. Arihara, "New cycloartane tripenoids from Passiflora edulis," Journal of Natural Products, vol. 63, pp. 1229-1234, August 2000.

[6] C. V. Silva, L. S. de Oliveira, and V. A. P. Loriato, "Organogenesis from root explants of commercial populations of Passiflora edulis Sims and a wild passion fruit species, P. cincinnata Masters," Plant Cell, Tissue and Organ Culture, vol. 107, pp. 407-416, June 2011.

[7] D. K. Isutsa, "Rapid Micropropagation of passion fruit (Passiflora edulis Sims.) varieties.," Scientia Horticulturae, vol. 99, pp. 395-400, February 2004.

[8] A. C. B. D. A. Monteiro, E. N. Higashi, A. N. Goncë Alves, and A. P. M. Rodriguez, "A novel approach for the definition of the inorganic medium components for micropropagation of yellow passion fruit (Passiflora edulis Sims. f. flavicarpa Deg.)," In Vitro Cellular and Developmental Biology - Plant, vol. 36, pp. 527- 531, November December 2000.

[9] L. M. Winkler and M. Quoirin, "Organogenesis and genetic transformation of yellow passion fruit (Passiflora edulis $\mathrm{f}$. flavicarpa Deg.) with the genes $C M e-A C O 1$ and nptII via Agrobacterium tumefaciens," Acta Horticulture, vol. 632, pp. 31- 40, 2002.

[10] M. C. Dornelas and M. L. C. Vieira, "Plant regeneration from protoplast cultures of Passiflora edulis var. flavicarpa Deg., $P$. amethystine Mikan. and P. cincinnata Mast," Plant Cell Reports, vol. 13, pp. 103-106, December 1993.

[11] A. P. C. Pinto, A. C. B. A. Monteuri-Hara, L. C. L. Stipp, and B. M. J. Mendes, "In vitro organogenesis of Passiflora alata," In Vitro Cellular \& Developmental Biology - Plant, vol. 46, pp. 28-33, September 2009.

[12] T. Murashige and F. Skoog, "A revised medium for rapid growth and bioassay with tobacco tissue culture," Physiologia Plantarum, vol. 15, pp. 473-497, March 1962.

[13] S. M. A. Zobayed, J. Armstrong, and W. Armstrong, "Leaf anatomy of in vitro tobacco and cauliflower plantlets as affected by different types of ventilation," Plant Science, 161, pp. 537-548, August 2001.

[14] S. P. Lombardi, H. R. S. Passos, M. C. S. Nogueira, and B. Appezzato-da-Gloria, "In vitro shoot regeneration from roots and leaf discs of Passiflora cincinnata Mast," Brazilian Archives of Biology and Technology, vol, 50, no. 2, 239-247, March 2007.

[15] M. R. Davey, P. Anthony, J. B. Power, and K. C. Lowe, "Isolation, culture, and plant regeneration from leaf protoplasts of Passiflora," in 
Methods in Molecular Biology 318: Plant Cell Culture Protocols, 2nd ed. V. M. L. Vargas, F. V. Flota, Springer, pp. 201-210, 2006.

[16] N. O. Amugene, H. N. B. Gopalan, and B. Bytebier, "Leaf disc regeneration of passion fruit," African Crop Science Journal, vol. 1, no 2, pp. 99-104, December 1993.

[17] N. Mohamed and R. M. Taha, "Plant regeneration of Clitoria ternatea from leaf explants cultured in vitro," Journal of Food, Agriculture and Environment, vol. 9, no. 3\& 4, pp. 268-270, July - October 2011.

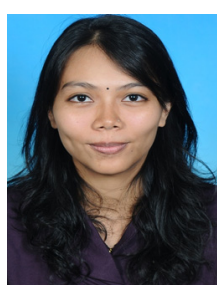

Rubashiny Veeramohan was born in Pahang, Malaysia on February 19, 1987. She obtained her B.Sc. (Hons.) in Industrial Biotechnology from University of Selangor, Shah Alam, Malaysia and is currently pursuing her M.Sc. (Except Maths and Science Philosophy) in the University of Malaya, Kuala Lumpur, Malaysia.

She is currently appointed as a research assistant at Institute of Biological Sciences, Faculty of Science, University of Malaya, Kuala Lumpur, Malaysia. She has published one editorial article in the Malaysian Journal of Science which is Scopus-cited.

Ms. Veeramohan's current research interest includes plant biotechnology (tissue culture) and plant taxonomy. Her previous research interest was environmental management.

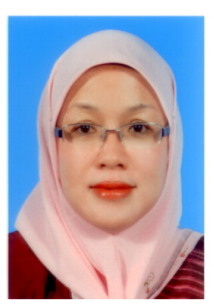

Noorma Wati Haron was born in Kedah, Malaysia on May 2, 1961. She obtained her B.Sc. (Hons.) degree in Botany at the University of Malaya, Kuala Lumpur, Malaysia in 1985. Dr. Noorma obtained her Ph.D degree in Higher Plant Taxonomy at the University of Reading, United Kingdom in 1991.

She was a lecturer at the Botany Department (currently known as the Institute of Biological Sciences), University of Malaya, Kuala Lumpur,
Malaysia from 1991-1998. She was appointed as an Associate Professor in 1998. She has been publishing her work in many international and local journals such as Blumea, Biochemical Systematics and Ecology, Botanical Journal of Linnean Society, The Scientific World Journal, Current Medicinal Chemistry, Australian Systematic Botany and Pakistan Journal of Biological Sciences. Her research interest includes plant biodiversity and conservation.

Dr. Haron has received Seameo Biotrop Conference Grant in 1992 and 1996 and is a member of ISHS.

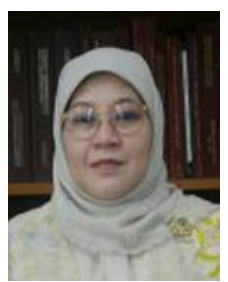

Rosna Mat Taha was born in Malaysia on January 22, 1958. In 1984, she obtained her B.Sc. in Botany from University of Malaya, Kuala Lumpur, Malaysia and eventually completed her Ph.D in 1989 on Plant Morphogenesis from University of Wales, Cardiff, UK.

She is currently working as a lecturer (professor) at Institute of Biological Sciences, Faculty of Science, University of Malaya, Kuala Lumpur, Malaysia. She has published more than 100 papers in ISI-cited journals, proceedings, book chapters and etc.

Prof. Taha is also an expert in plant tissue culture, morphogenesis, biotechnology, pigment and cellular behavior studies. She has won many awards (more than 20) in her research. She is a member of European Association for Research on Plant Breeding (EUCARPIA) and International Society for Horticultural Science (ISHS). Also, she is the associate editor of Asian Journal of Biotechnology, Asian Journal of Plant Sciences and Journal of Applied Sciences. 